\title{
AGRICULTURAL ENTERPRISE MANAGEMENT REPORT
}

\author{
H. V. UMEROVA, Graduate Student ${ }^{*}$, Department of Accounting and Taxation \\ ORCID 0000-0001-9532-7265 \\ National University of Life and Environmental Sciences of Ukraine \\ E-mail: ann.umerova@nubip.edu.ua
}

\begin{abstract}
The article is devoted to the organizational and basic procedures of the Management Report's structural synthesis and informational content. This reporting form introduction is due to the implementation of the Directive 2013/34/EU provisions "On annual financial statements, consolidated financial statements" in the legislation of Ukraine. Accordingly, the requirement has been established for large enterprises, including public interest entities, to prepare a Management Report concerning the financial and non-financial information disclosing.

Management Report is an information support source and a comprehensive assessment of the state and potential, financial, economic, social, labor and environmental enterprise activities, identified risks and uncertainties, etc. The information obtained allows both internal and external users to assess the consequences of the enterprise activities impact on the environment, society and the economy, in particular, the certain segment development potential.

Domestic and international regulatory support on the Management Report preparation has been analyzed as part of the study. The Management Report content has been proposed in accordance with the requirements of different management levels particularly concerning disclosing relevant information on agricultural enterprise activities in economic, social and environmental areas.

The implementation of these recommendations will provide information on the results and specifics of agricultural enterprise activities; the headcount analysis and the social policy state in general at enterprises; impact on the environment and mechanisms to minimize it. It also has determined that disclosing these key performance indicators contributes to the increase in information transparency, accountability and comparability, as well as agricultural enterprise investment attractiveness and sustainable development.
\end{abstract}

Keywords: Management Report, non-financial reporting, economic, social and environmental indicators, risks, public interest entities, agricultural enterprises.

Introduction. Harmonization of Ukraine's accounting and financial reporting takes place by approaching European norms and international standards for doing business. This is due to the need to meet data requirements significantly for internal

\footnotetext{
* Scientific supervisor - Doctor of Economic Science, Professor Ye. V. Kaliuha
} 
and external users in terms of disclosing both financial and non-financial information by business entities in accounts and records. Lack of list, structure, and content of non-financial indicators in accounts and records approved at the legislative level leads to an inability to satisfy the stakeholders' requests on the business entities state and development potential, their impact on the economy, the environment, and society as a whole, identify all possible risks and uncertainties faced by enterprises by their practice. Therefore, there is a need to ensure the relevant financial and nonfinancial information disclosing in the Management Report in order to increase the business entities' transparency, their investment attractiveness, and sustainable development. Presently, agricultural enterprises experience problems with the Management Report drawing up. This determines the relevance of the methodological development for the Management Report informational content, in the light of the area-specific features.

Analysis of recent researches and publications. The works of many scholars are devoted to theoretical and practical issues on the content and structure of the Management Report drawing up, in particular: T. A. Bondar, O. V. Handziuk, Ye. V. Kaliuha,
L. H. Lovinska,
D. V. Liudvenko,
A. V. Ozeran, Ya. V. Oliinyk, V. P. Panteleieva, N. O. Tomilova and others.

Based on the research results conducted by L. H. Lovinska, Ya. V. Oliinyk, and T. A. Bondar [6], methodology proposals on the Management report structure and informational content of domestic enterprises have been highlighted. In addition, L. H. Lovinska [5] lists the Management Report components, its objectives, and area of application, while T. A. Bondar [1] highlights the Management Report drawing up phases. In the work of Ye. V. Kaliuha [4], the regulatory support of the extractive sector, which will contribute to the theoretically grounded structuring of the Transparency Report, has been analyzed. Research by A. V. Ozeran [10] has shown that the Management Report is an integral part of the financial statements. Research results by D. V. Liudvenko and N. A. Tomilova [7] have become the livestock section presentation in the Management Report concerning disclosing the accounting 
information on engineering and manufacturing, financial, and economic indicators of livestock products.

At the same time, the analysis of recent research by leading scholars on the state and development of non-financial reporting, namely the Management Report, determines the relevance of the consideration for vulnerabilities in the Management Report methodological and organizational support.

The purpose of the article is to develop methodological proposals for the Management Report structure and informational content to the requirements of different management levels particularly concerning disclosing the relevant information about agricultural enterprise in economic, social, and environmental areas.

Materials and methods of research. During the research, the following methods of cognition were used: induction and deduction, analysis and synthesis, comparison, systematization, classifications, etc.

Results of the research and their discussion. Within the framework of implementing the Directive 2013/34/EU provisions "On annual financial statements, consolidated financial statements" [15], amendments have been made to the Ukrainian legislation "On accounting and financial reporting in Ukraine" [12], there has been established a requirement for certain business entities to draw up a Management Report. It contains financial and non-financial information characterizing the enterprise state and development potential; reveals the risks and uncertainties of its activities. Large enterprises, including public interest entities, are obliged to submit it, while medium-sized enterprises have the right to submit a Management Report in abridgment, highlighting only the financial indicators of their activities. Micro and small businesses grant relief from submitting the Report. Selected businesses must draw up and submit a Management Report together with the financial and consolidated financial statements and publish it on the company's website since 2018. As of 01.01.2020, the number of large-sized entities, obliged to draw up a Management Report, totaling 517 units, including agricultural enterprises - 
33 units [11]. It should be noted that namely these enterprises play a decisive role in the domestic economy.

Agricultural enterprises, engaged in the crop production, operate within the venturousness and uncertainty; this is due to external factors (reduced public support for agricultural sector, seasonality and instability of production due to various natural and climatic factors, the agricultural effective crediting underdevelopment) and internal ones (outdated plant, lack of innovation, lack of current assets). The solution to these problems is possible under the condition of data intelligence of the crop production manufacturing in accordance with the market relations requirements. The necessity for drawing up a Management Report is due to the need for internal users to understand synergies between both the enterprise performance and the outside processes, which, in turn, helps to reduce polluting emissions, improve conditions, and increase the gross rate of productivity; improve business reputation, increase enterprise investment attractiveness; comply with regulations applying to domestic enterprises. In addition, the external users' requirements (shareholders, suppliers, contractors, investors, scientists, media, community) in obtaining information on the business entities prospects and their impact on the environment is an important factor in disclosing the non-financial performance index of large enterprises in accounts and records. In this regard, when the Management Report is drawing up, it is necessary to disclose relevant enterprise information, which will help stakeholders make decisions concerning its impact on the economy, environment, society, and the effect of activities. This ensures transparency of business entities, favorable investment climate, stability in the enterprise development, etc.

Thus, the form, structure, and content of the Management Report is not regulated and generated by enterprises independently in any form, taking into account the Methodological Recommendations for its drawing up [13] (Table 1). Conducted analysis of the Management report proposed structure has shown that it includes 10 areas. As far as we are concerned, the most significant areas among them are operating results, environmental aspects, social aspects, HR policy, and risks. In 
particular, these areas need to be paid attention when developing the content proposals.

In addition, Directive 2013/34/EU 'On annual financial statements, consolidated financial statements" [15] states that the Management Report is a balanced and comprehensive analysis of financial and non-financial indicators, in particular, it discloses precise information on the enterprise development and its state, the environment and personnel, financial risk management policies, including price, credit, liquidity risk, and flow of monies.

\section{Management Report information disclosing in compliance with}

\section{Methodological Recommendations on the Management Report drawing up}

\begin{tabular}{|c|c|c|}
\hline $\begin{array}{l}\text { S. } \\
\text { No. }\end{array}$ & List of areas & List of indicators \\
\hline 1 & $\begin{array}{l}\text { Organizational } \\
\text { pattern and } \\
\text { activity } \\
\text { description }\end{array}$ & $\begin{array}{l}\text { Organizational pattern of the enterprise; strategy and goals; } \\
\text { geographical and sectorial services; enterprise share in the market } \\
\text { segment, etc. }\end{array}$ \\
\hline 2 & Operating results & $\begin{array}{l}\text { Operating results taking into account the enterprise development } \\
\text { potential. }\end{array}$ \\
\hline 3 & $\begin{array}{l}\text { Liquidity and } \\
\text { legal liability }\end{array}$ & $\begin{array}{l}\text { Assets that ensure timely fulfillment of liabilities; accountable } \\
\text { liabilities, their types and terms of payment; indirect liabilities, their } \\
\text { types and assessment of possible influence on the liquidity; factors that } \\
\text { affect or may affect liquidity in the future. }\end{array}$ \\
\hline 4 & $\begin{array}{l}\text { Environmental } \\
\text { aspects }\end{array}$ & $\begin{array}{l}\text { Indicators characterizing rational use of water; waste management; } \\
\text { greenhouse gas emissions; energy consumption. }\end{array}$ \\
\hline 5 & $\begin{array}{l}\text { Social aspects } \\
\text { and HR Policy }\end{array}$ & $\begin{array}{l}\text { Total number of employees and proportion of women in executive } \\
\text { positions; encouraging employees; labor protection and safety; } \\
\text { occupational training and education; equal employment opportunities; } \\
\text { respect for human rights; efforts to crack down on corruption and } \\
\text { bribery. }\end{array}$ \\
\hline 6 & Risks & $\begin{array}{l}\text { The enterprise policy for managing operational and financial risks with } \\
\text { a description of their impact on activities; tools used to reduce the } \\
\text { impact of these risks on its activities, etc. }\end{array}$ \\
\hline 7 & $\begin{array}{l}\text { Research and } \\
\text { innovations }\end{array}$ & $\begin{array}{l}\text { Research, innovative activities and } \mathrm{R} \& \mathrm{D} \text { products carried out by the } \\
\text { enterprise; costs for such activities and their impact on activities. }\end{array}$ \\
\hline 8 & $\begin{array}{l}\text { Financial } \\
\text { investments }\end{array}$ & $\begin{array}{l}\text { Financial enterprise investments in other enterprise securities, in } \\
\text { associated undertakings, subsidiaries, etc. }\end{array}$ \\
\hline 9 & $\begin{array}{l}\text { Development } \\
\text { potential }\end{array}$ & $\begin{array}{l}\text { The enterprise further development potential, taking into account the } \\
\text { risks and challenges to implementing the activities. }\end{array}$ \\
\hline 10 & $\begin{array}{l}\text { Corporate } \\
\text { management }\end{array}$ & $\begin{array}{l}\text { Staff of governing bodies, corporate governance strategies; the } \\
\text { shareholders' structure and their shares in corporate stock; securities } \\
\text { holders with special control rights; the enterprise activities concerning } \\
\text { transactions with own shares; principal features of the internal control } \\
\text { system; dividend policy; improving corporate governance, etc. }\end{array}$ \\
\hline
\end{tabular}

Source: formed by [13]. 
In exchange, this requires disclosing information on the main risks at the enterprise, their incidence on the activity and the external environment, causes of occurrence and measures to prevent risks. In addition, in accordance with the Directive 2014/95/EU provisions "On disclosing non-financial and diversified information by individual large enterprises and groups" [16], the Management Report must disclose information on a simple description of the ongoing enterprise model, the business entity policy concerning environmental and social aspects, employment issues, respect for human rights, corruption and bribery control, the above-mentioned policies results that have been achieved, noteworthy risks and key non-financial indicators relating to the relevant business.

Thus, domestic and international regulatory documents contain a wide list of indicators that can be highlighted in the Management Report in order to provide enterprises with a choice to disclose relevant information on the state and business development, impact on the environment, etc. It should be noted that when choosing digital indicators in most cases, preference should be given to those that do not require counting and are formed according to source documents, accounting registers, financial, statistical, and tax and management statements. The Management Report should be presented in such a way as to provide users with the ability to compare it with similar enterprise information for the same period last year, as well as with other business entities. Disclose policy may vary only if it leads to disclosing information on quality improvement as well as the Report as a whole [8]. This, in turn, ensures Management Report intersectoral comparability of various enterprises as well as standardization of approaches to draw them up.

As for the agricultural enterprise Management Report preparation, it is necessary to pay attention to the key indicators of the economic, environmental, and social areas, risks and uncertainties. As part of the research, the domestic legal and regulatory framework analysis [12; 13], European Directives [15; 16], and nonfinancial recording of domestic agricultural public interest entities $[3,9 ; 14 ; 17]$ has been carried out. On this basis, proposals for the Management Report informational 
content have been formulated in terms of disclosing relevant information on the economic, environmental, and social areas of agricultural enterprises (Table 2-4) in order to reflect the specifics and technological characteristics for crop production. It should be noted that a considerable part of the Management Report should be occupied by descriptive information as confirmation of digital data in dynamics as well as in an analytical context in various areas in order to increase the pro-forma financial statement benefits to meet users' needs.

The leading economic indicators of agricultural enterprises (see Table 2) are not complete and may vary depending on the enterprise goals.

\section{Key performance indicators of agricultural enterprises in the economic}

area

\begin{tabular}{|c|l|c|c|c|}
\hline $\begin{array}{c}\text { S } \\
\text { No. }\end{array}$ & \multicolumn{1}{|c|}{ Indicator } & $\begin{array}{c}\text { For the } \\
\text { accounting } \\
\text { period }\end{array}$ & $\begin{array}{c}\text { For the same } \\
\text { period last year }\end{array}$ & $\begin{array}{c}\text { Projection data } \\
\text { specifying the } \\
\text { change reasons }\end{array}$ \\
\hline 1 & Gross output, thousand tons & & & \\
\hline 1.1. & Predecessors of agricultural crops & & & \\
\hline 1.2. & Plant protection products & & & \\
\hline 1.3. & Seeding rate & & & \\
\hline 2 & Cost of goods sold, thousand UAH & & & \\
\hline 3 & Net operating income, thousand UAH & & & \\
\hline 4 & Taxes and charges, thousand UAH & & & \\
\hline 5 & Crop production area, hectare & & & \\
\hline 5.1. & Soil treatment & & & \\
\hline 5.2. & Soil fertilization & & & \\
\hline 6 & Land share rent charges, thousand & & & \\
\hline
\end{tabular}

Source: formed by the author.

It is worth noting that the represented data for the accounting period as well as for the same period last year are reported according to process card, financial statements (Balance (Statement of affairs) and Profit and Loss Account (Statement of total income)) and statistical statements (Statement of crop production area (form No. 4-ag), Report on the area and gross collection of agricultural crops, fruits, berries and grapes (form No. 29-ag), and the Report on leading economic indicators of agricultural enterprises (form No. 50-ag)). The projection data generation and their justification allow familiarizing stakeholders with the dynamics of their further development. 
One of the leading economic indicators characterizing agricultural enterprise activities is the volume of cultivated current biological assets of crop products. In the Management Report, it is necessary to disclose information on the droppings structure, namely, preceding agricultural crops, depending on climatic conditions, location, and structure of cropping patterns. It is also advisable to cover information on preparing seeds for sowing, which involves the introduction of plant protection products: pesticides, pest control chemicals, fungicides, herbicides, microelements, depending on the type and variety of crops. Information on the protection products application and seed sowing rates should be disclosed comparing standard values with actual use in order to correlate these data and find out the deviation reasons.

An interrelated indicator of the volume of products grown is the land area allocated for sowing agricultural crops; it is possible to calculate crop productivity thanks to these indicators (dividing the volume of products produced by the crop production area). Protection from weeds, moisture conservation during sowing, fertilization and dosage compensation are the main tasks for dressing and fertilizing crop production area. As far as we are concerned, in the agricultural enterprise Management Report, it is necessary to disclose such technological features of the biological assets cultivation for crop production in order to analyze the decisions made on production methods, the volume of crop production received, incurred expenses for its cultivation.

Crop production costs, net operating income, and other economic indicators depend on the size of the crop production area, the soil dressing and its fertilizing. Besides, the majority of public interest entities for crop production use land under tenancy, therefore, in our opinion, the land share rental expenses are also a key indicator that needs to be highlighted in the Management Report.

The next area in the Management Report is social and HR policy indicators of the agricultural enterprise (see Table 3), which are mostly pulled from statistical reporting, namely the Labor Report (form 1-PV). 


\section{Key performance indicators of agricultural enterprises in the social area}

\begin{tabular}{|c|c|c|c|}
\hline $\begin{array}{l}\text { S. } \\
\text { No. }\end{array}$ & Indicator & $\begin{array}{c}\text { For the } \\
\text { accounting } \\
\text { period }\end{array}$ & $\begin{array}{l}\text { For the same } \\
\text { period last year }\end{array}$ \\
\hline 1 & The total quantity of regular employees & & \\
\hline 2 & Share of the seasonal labor force, $\%$ & & \\
\hline 3 & Proportion of women in executive positions, $\%$ & & \\
\hline 4 & $\begin{array}{l}\text { The total quantity of non-personnel establishment } \\
\text { workers }\end{array}$ & & \\
\hline 5 & Labor fluctuations & & \\
\hline 6 & Wages of regular employees, thousand UAH & & \\
\hline 7 & Wages of the seasonal labor force, thousand UAH & & \\
\hline 8 & Wages of female employees, thousand UAH & & \\
\hline 9 & $\begin{array}{l}\text { Wages of non-personnel establishment workers, } \\
\text { thousand UAH }\end{array}$ & & \\
\hline 10 & Average wages within the company, UAH & & \\
\hline 11 & $\begin{array}{l}\text { Welfare expenditures, cultural and social services of } \\
\text { employees, thousand UAH }\end{array}$ & & \\
\hline 12 & $\begin{array}{l}\text { Costs for employee provision of housing, thousand } \\
\text { UAH }\end{array}$ & & \\
\hline 13 & Costs for occupational training, thousand UAH & & \\
\hline 14 & Costs for job safety, thousand UAH & & \\
\hline 15 & Observance of human rights & & \\
\hline
\end{tabular}

Source: formed by the author.

As far as we are concerned, in the HR policy context, it is necessary to disclose information on the employees' structure based on gender, highlighting the proportion of women in executive positions, as well as by wage labor type - regular and temporary staff. Besides, it is advisable to allocate the seasonal workers from the regular staff in order to determine their importance and role in performing agricultural work. And the staff turnover indicator allows to identifying its level, the enterprise slate of internal talent, the factors (salary level, lack of career growth, available jobs, corporate housing for non-resident workers, etc.), company losses, and measures to reduce staff turnover. The next group of the social policy indicators is the salary budget for regular (including seasonal workers and women) and temporary staff with disclosing information on the remuneration system and motivation, the salary budget structure (components of basic and extra wages, other incentive and compensation payments), etc. These data determine the average wage at the enterprise as a whole and compare it with the minimum wage determined by the legislation of Ukraine and the average wage within a particular area. 
Labor maintenance costs that are not part of the payroll are important. These include social security costs (health insurance costs, a pecuniary compensation for retiring workers, enterprise costs to pay for treatment services for workers, etc.), cultural and social services (maintenance of canteens, dispensaries, sanatoriums, holiday centers, recreation camps, etc.), provision of housing (housing construction for employees, maintenance of the residential areas, which are on the enterprise books, etc.), vocational training (payment for training employees in higher educational institutions and establishments, advanced vocational training, professional training, and retraining, etc.), labor protection (providing employees with special clothing, footwear, and other personal protective equipment, performance appraisal system, etc.). The represented data disclose information on additional labor and social benefits for employees. And the human rights indicator contains information on job security for employees with disabilities and those of preretirement and retirement age. The information disclosing enables users to familiarize themselves with the social enterprise policies that provide social protection to such persons and improve their financial situation through employment.

In addition, information on the enterprise's impact on the environment in the Management Report should be disclosed in the enterprise environmental area (see Table 4).

\section{Key performance indicators of agricultural enterprises in the environmental} area

\begin{tabular}{|c|l|c|c|}
\hline $\begin{array}{c}\text { S. } \\
\text { No. }\end{array}$ & \multicolumn{1}{|c|}{ Indicator } & $\begin{array}{c}\text { For the } \\
\text { accounting } \\
\text { period }\end{array}$ & $\begin{array}{c}\text { For the same } \\
\text { period last year }\end{array}$ \\
\hline 1 & Soil fertilization & & \\
\hline 2 & Water abstraction, thousand cubic meter & & \\
\hline 3 & Common reset of sewages, thousand cubic meter & & \\
\hline 4 & Water use efficiency & & \\
\hline 5 & Energy volume, kilowatt-hour & & \\
\hline 6 & Total consumption of fuels, TJ & & \\
\hline 7 & Volume of greenhouse gases emissions, \% & & \\
\hline 8 & Renewable energy, \% & & \\
\hline 9 & Gross weight of waste products, tonne & & \\
\hline 10 & Volume of recovered wastes, tonne & & \\
\hline 11 & Volume of recycled wastes, tonne/thousand UAH & & \\
\hline
\end{tabular}

Source: formed by the author. 
Key indicators characterizing the agricultural enterprise's impact on the environment are soil fertility, use of water resources and energy, greenhouse gas emissions, wastes generation, recycling, and disposal. Soil degradation is observed during the long-term agricultural land use, mostly rented by large enterprises. That is why, it is important to cover in the Management Report relevant information on soil fertility indicators and a package of measures for protecting and preserving the productivity of agriculturally used areas, increasing their environmental sustainability and fertility. In turn, its achievement is facilitated by the construction of a just-in-time soil inventory and its qualitative characteristics, rational and environmentally friendly land use, the maintenance of soil fertility indicators in a stable state and their improvement through the compliance with measures to protect soils from negative natural and anthropogenic impacts or minimize the manifestation impact, etc. The represented data confirm the responsible attitude to land conservation and the willingness of agricultural enterprises to work on solving problems that arise.

In the process of crop products cultivating at agricultural enterprises, it is important to use water resources efficiently. In our knowledge, in the agricultural enterprise Management Report, it is necessary to reflect information on the total water use, with the water withdrawal point delimitation (surface, groundwater, sewages from other enterprises, municipal and other water supply systems) and the places of wastewater disposal (through pipes to public owned treatment facilities, into cesspools with removal to public owned treatment facilities, release into a water body after cleaning at own treatment facilities, etc.). The water use efficiency indicator is calculated by the ratio of the total volume of water intake to the volume of crop products. Disclosing such information to stakeholders means managing water resources responsibly.

Energy consumption during production, treatment, and storage of crop products affects the environment throughout the entire production cycle. In the Management Report on this issue, it is necessary to disclose data on the state of electricity and fuel consumption, information on energy consumption management, aimed at reducing 
the electricity consumption in general and fuels from renewable sources (natural gas, diesel fuel, gasoline) and increasing fuel consumption from renewable sources (biogas, sunflower seed husks); this is an important component of sustainable enterprise development.

Greenhouse gas emissions by agricultural enterprises tend to increase [11]. The largest emission sources in crop production are synthetic fertilizers, natural gas burning, diesel fuel, and gasoline, etc. Therefore, the enterprise is obliged to provide information on pollution emissions and greenhouse gases, explain their generation reasons and the reduction strategy.

In the process of crop production, various types of both non-hazardous wastes (straw, grain waste) and hazardous ones (pesticide packaging, used storage batteries, and lubricants) are generated. As far as we are concerned, it is advisable to provide waste information in the behavioral practice context: repeated and multiple applications of waste products, composting, separation of valuable components, incineration, disposal at a landfill, transfer to contractual partner under an agreement, etc. Such analytical data decoding allows users to evaluate measures for preventing, collecting, transporting, sorting, storing, treating, recycling, recovering, weeding, decontaminating, and disposing of waste products.

In addition, when drawing up the Management Report, special attention should be paid to the risks and difficulties that agricultural enterprises face during their activities, and to highlight the management approaches. Agriculture is a risky field of activities because it depends not only on the financial and economic situation, but also directly on the natural and climatic conditions, soil fertility, and natural disasters. An effective risk management tool for crop products is agricultural insurance as a mechanism for a partial refund of losses in case of an agricultural product's dearth due to unfavorable weather and climatic conditions. In addition to the natural (production) risk, in the process of agricultural production, there appear technologyrelated, anthropogenic, radiological and eco-economic, market (price), institutional and financial risks. Technology-related risk arises as a result of water saturation of lands, soil pollution with chemicals, and, as a consequence, a decrease in yield, 
deterioration of the soil quality characteristics. Disruptions of natural balance, loss of soil cover, nutrient depletion are the anthropogenic impact consequences on agriculturally used areas. Radiological risk arises from ionizing radiation materials in the environment and their entry into crop production. The use of environmentally hazardous technologies in agricultural production generates environmental and economic risks in agricultural enterprise activities [2]. Price risk is associated with price changes for seeds, fuel, plant protection products, etc. Changes in legislation create institutional risk. Credit instruments for enterprises are associated with financial risks. Taking into account the abovementioned arguments, this issue should be covered in a separate section of the Management Report. The description of significant risk types should cover both negative consequences as well as potential opportunities. This enables both external and internal users to assess the enterprise risks and uncertainties, and get acquainted with the enterprise management strategy to minimize risks for agriculture.

Conclusions and future perspectives. The research conducted allows us to assert that drawing up a Management Report regarding the proposed list of economic, social, and environmental indicators of agricultural enterprises contributes to an increase in information transparency, accountability, and comparability in the enterprise context compared with these areas of activity. In addition, it is worth noting that the Management Report should disclose relevant and descriptive information understandable to users regarding these key indicators using illustrative material (pictures, graphs, diagrams) to perceive and analyze such data.

The proposed recommendations implementation will make it possible to disclose information in the economic aspect on the agricultural enterprise results, its specificity and the activity technological features, in the social aspect - the headcount analysis and the social policy state in general at enterprises, and in the environmental aspect - impact on the environment and mechanisms to minimize it. In turn, this will satisfy the information needs of both internal and external users on the consequences of the enterprise performance impact on the domestic economy, in particular, the development of the crop production, the environment, and society. 


\section{References}

1. Bondar, T. A. (2017). Zvit pro upravlinnia: etapy skladannia [The report about management: phases of compilation], Suchasni tendentsii rozvytku obliku, opodatkuvannia, analizu $i$ audytu: proceedings of international scientific and practical conference. Kyiv: KNEU. Retrieved from https://ir.kneu.edu.ua/bitstream/handle/2010/23374/115-17.pdf?sequence=1\&is Allowed=y (in Ukrainian).

2. Vovchak, O. D. (2005). Strakhuvannya [Insurance]. Lviv: "Novyi svit 2000". (in Ukrainian).

3. Sustainability Report for 2019 "Astarta-Kyiv". (2020). Retrieved from https://astartaholding.com/files/uploads/07e490bb8294f09d3f8cfdda3ea3017a.pdf.

4. Kaliuha, Ye. V. (2017). Normatyvno-pravove zabezpechennia subiektiv dobuvnoi haluzi v konteksti formuvannia Zvitu pro prozorist [Regulatory and legal provision of the extractive industry enterprises in the context of the formation of the Transparency Report]. Visnyk Ternopilskoho natsionalnoho ekonomichnoho universytetu, 4, 159-172. Retrieved from http://nbuv.gov.ua/UJRN/Vtneu_2017_4_17. (in Ukrainian).

5. Lovinska, L. H. (2014). Vplyv yevrointehratsiinykh protsesiv na rozvytok bukhhalterskoho obliku ta zvitnosti $\mathrm{v}$ Ukraini [The impact of european integration processes on the development of accounting and reporting in Ukraine]. Finansy Ukrainy, 9, 21-30. Retrieved from http://finukr.org.ua/docs/FU_14_09_021_uk.pdf (in Ukrainian).

6. Lovinska, L. H., Oliinyk, Ya. V., \& Bondar, T. A. (2018). Normatyvnopravove zabezpechennia Zvitu pro upravlinnia pidpryiemstv v Ukraini [Regulatory and legal basis for enterprise Management report in Ukraine]. Finansy Ukrainy, 6, 19-44. Retrieved from http://finukr.org.ua/docs/FU_18_06_019_uk.pdf (in Ukrainian).

7. Liudvenko, D. V., \& Tomilova, N. O. (2020). Zvit pro upravlinnia ta predstavlennia tvarynnytstva $\mathrm{v}$ intehrovanii zvitnosti [Management report and representation of animal husbandry in integrated reporting]. International forum: problems and scientific solutions, 32-37. Retrieved from https://ojs.ukrlogos.in.ua/index.php/interconf/article/view/3612/3533 (in Ukrainian).

8. Guidelines for the preparation of the Management Report from Kreston GCG. (2020). Retrieved from https://kreston-gcg.com/ua/methodical-recommendations-forthe-training-of-zv\%D1\%96tu-about-the-management-of-kreston-gcg/.

9. Non-financial report for 2019 Agro\&Industrial holding "Mironivsky Hliboproduct". (2020). Retrieved from https://www.mhp.com.ua/library/file/mhp-nfrfinal.pdf

10. Ozeran, A. V. (2018). Zvit kerivnytstva: sutnist', struktura ta mistse u systemi finansovoi zvitnosti sub'iekta hospodariuvannia [Management report: nature, structure and place in the financial reporting system of the entity]. Ekonomika $i$ suspil'stvo, 18, 983-993. $\quad 10$ Retrieved from http://www.economyandsociety.in.ua/journal/18_ukr/137.pdf (in Ukrainian). 
11. The official site of the State Statistics Service of Ukraine. (2020). Retrieved from http://www.ukrstat.gov.ua/operativ/operativ2018/ns/vzap/arch_vzrap_u.htm.

12. Verkhovna Rada of Ukraine. (1999). Pro bukhhalters 'ky’j oblik ta finansovu zvitnist' $v$ Ukrayini [On accounting and financial reporting in Ukraine] (Act No. 996XIV, July 16). Retrieved from http://zakon3.rada.gov.ua/laws/show/996-14 (in Ukrainian).

13. Ministry of Finance of Ukraine. (2018). Pro zatverdzhennia Metodychnykh rekomendatsii zi skladannia zvitu pro upravlinnia [On Approval of the Guidelines for the preparation of the management report] (Order No. 982, December 7). Retrieved from https://zakon.rada.gov.ua/rada/show/v0982201-18 (in Ukrainian).

14. Social reports of "Nibulon". (2020). Retrieved from https://www.nibulon.com/data/ksv/socialni-zviti.html.

15. European Union. (2013). Directive 2013/34/EU of the European Parliament and of the Council of 26 June 2013 on the annual financial statements, consolidated financial statements and related reports of certain types of undertakings. Retrieved from http://eur-lex.europa.eu/legal-content/EN/TXT/?uri=celex\%3A32013L0034.

16. European Union. (2014). Directive 2014/95/EU of the European Parliament and of the Council of 22 October 2014 amending Directive 2013/34/EU as regards disclosure of nonfinancial and diversity information by certain large undertakings and groups. $\quad$ Retrieved from http://eurlex.europa.eu/legalcontent/EN/TXT/PDF/?uri=CELEX:32014L0095\&from=en.

17. Sustainability report 2019 "Goodvalley". (2020). Retrieved from http://svb.ua/sites/default/files/csr19.pdf.

\title{
ЗВІТ ПРО УПРАВЛІННЯ НА СІЛЬСЬКОГОСПОДАРСЬКИХ ПІДПРИЕМСТВАХ
}

\author{
Г. В. Умерова
}

Анотація. Стаття присвячена організаційним і методичним засадам формування структури та інформаційного наповнення змісту Звіту про управління. Запровадження иієї форми звітності обумовлене імплементацією положень Директиви 2013/34/СС «Про шорічну фінансову звітність, консолідовану фінансову звітність» у законодавство Украӥни. Відповідно до ивого встановлено вимогу до великих підприємств, у тому числі суб'єктів суспільного інтересу, формувати Звіт про управління у частині розкриття фінансової та нефінансової інформації.

Звіт про управління $е$ джерелом інформаиійного забезпечення та комплексної оцінки стосовно стану та розвитку підприсмств, фінансової, економічної, сочіально-трудової та екологічної діяльності, виявлених ризиків $i$ невизначеностей тощь. Отримана інформація надає можсливість внутрішнім $i$ зовнішнім користувачам оиінити наслідки впливу діяльності підприємств на довкілля, суспільство та економіку, зокрема, на розвиток певної галузі. 
У ході проведеного дослідження проаналізовано вітчизняне та міжнародне нормативно-правове забезпечення щодо формування Звіту про управління. Запропоновано інформащійне наповнення змісту Звіту про управління відповідно до вимог різних рівнів управління у частині розкриття суттєвої інформації щодо економічної, соціальної ци екологічної сфер діяльності сільськогосподарських підприємств.

Впровадження зазначених рекомендачій надасть можливість отримати інформацію щуодо результатів і специфіки діяльності сільськогосподарських підприємств; ефективності використання трудового потенціалу та стану соціальної політики в цілому на підприємствах; впливу на навколишнє середовище та механізмів його мінімізації. Визначено, щуо розкриття наведених ключових показників діяльності сприяє підвищенню прозорості, підзвітності та порівнянності інформації, а також інвестиційній привабливості та сталому розвитку сільськогосподарських підприємств.

Ключові слова: Звіт про управління, нефінансова звітність, економічні, сочіальні та екологічні показники, ризики, суб'єкти суспільного інтересу, сільськогосподарські підприємства. 